\title{
Pulsatile hormone secretion during the first ovarian follicular wave in Bos indicus heifers
}

\author{
F. M. Rhodes ${ }^{1}$, L. A. Fitzpatrick ${ }^{I}$, K. W. Entwistle ${ }^{I *}$ and \\ J. E. Kinder ${ }^{2}$ \\ ${ }^{1}$ Department of Biomedical and Tropical Veterinary Sciences, James Cook University of North \\ Queensland, Townsville, Q4811. Australia; and ${ }^{2}$ Department of Animal Science, University of \\ Nebraska, Lincoln. NE 68583-0908, USA
}

\begin{abstract}
Introduction
Characteristics of pulsatile hormone release have been examined during the early and mid-luteal stages of the bovine oestrous cycle; the frequency of pulses of $\mathrm{LH}$ was greater during early than during mid-luteal phases (Rahe et al., 1980; Walters et al, 1984), However, changes in gonadotrophin and ovarian steroid secretion have not been examined in relation to the morphological changes of the first dominant follicle. It is necessary to collect venous samples at a site close to the ovary to obtain accurate measurements of ovarian steroid secretion. In the study reported here, the caudal vena cava was catheterized via the lateral saphenous vein, with the aim of evaluating changes in concentrations of LH, $\mathrm{FSH}$, oestradiol and progesterone during the growth, early plateau and regression phases of the first dominant follicle of the oestrous cycle in heifers.
\end{abstract}

\section{Materials and Methods}

The ovaries of five Brahman (Bos indicus) heifers were examined daily using transrectal ultrasonography (7,5 MHz transducer, Aloka $210 \mathrm{DX})$ for two interovulatory intervals. The size and position of corpora lutea and all follicles $\geq 5 \mathrm{~mm}$ were recorded as described by Savio et al. (1988). Serial blood samples were collected during the second interovulatory interval for three sampling periods defined with reference to the growth of the first dominant follicle: period I (growth phase) when a follicle $\geq 7 \mathrm{~mm}$ diameter was first detected; period 2 (plateau phase) when there had been no increase in size of the dominant follicle after $24 \mathrm{~h}$; period 3 (regression phase) when the dominant follicle started to decrease in size or the second wave of follicles had emerged.

Before the first day of serial blood collection, the caudal vena cava was catheterized using a modification of the technique of Benoit and Dailey (1991), in which a polyethylene catheter (1 mm id., $2 \mathrm{~mm}$ o.d.) containing a wire guide was introduced into the caudal vena cava via the saphenous vein. Placement of the catheter within the caudal vena cava was confirmed using transrectal ultrasonography as described by Norman and Fields (1993), with the tip of the wire guide positioned medially to the body of the left kidney. This position corresponds to the site of maximum concentration of progesterone in caudal vena cava blood. On specified days of collection, samples were obtained every $15 \mathrm{~min}$ for $24 \mathrm{~h}$ and subsequently assayed for LH (F. M. Rhodes, L. A. Fitzpatrick, K. W. Entwistle and J. E. Kinder, unpublished), FSH (Wolfe et al., 1989), oestradiol (Kojima et al., 1992) and progesterone (Jolly, 1992) in plasma. Jugular plasma samples were also obtained daily for the complete interovulatory interval and assayed for the same hormones.

Mean concentration, frequency and amplitude of pulses for each hormone were determined using a pulse analysis program (PULSAR; Merriam and Wachter, 1982) for each animal for the separate periods of blood collection. Differences in these hormone characteristics due to sampling period were evaluated by paired $t$ tests.

*Present address: Faculty of the Sciences, The University of New England, Amidale NSW 2351, Australia. 
Table 1. Mean hormone concentrations in the caudal venae cavae of five heifers during three sampling periods defined with reference to the growth of the first dominant follicle

\begin{tabular}{lcrrr}
\hline \multicolumn{4}{c}{ Hormone } \\
\cline { 2 - 5 } Period & $\begin{array}{c}\text { LH } \\
\left.(\mathrm{ng} \mathrm{ml})^{-1}\right)^{b}\end{array}$ & \multicolumn{1}{c}{$\begin{array}{c}\text { FSH } \\
\left(\mathrm{ng} \mathrm{ml}^{-1}\right)^{\mathrm{c}}\end{array}$} & $\begin{array}{r}\text { Oestradiol } \\
\left.(\mathrm{pg} \mathrm{ml})^{-1}\right)^{\mathrm{b}}\end{array}$ & \multicolumn{1}{c}{$\begin{array}{c}\text { Progesterone } \\
\left(\mathrm{ng} \mathrm{ml}^{-1}\right)^{\mathrm{b}}\end{array}$} \\
\hline 1 & $0.43 \pm 0.05$ & $1.77 \pm 0.07$ & $11.49 \pm 2.67$ & $6.74 \pm 2.98$ \\
2 & $0.36 \pm 0.04$ & $1.86 \pm 0.03$ & $3.07 \pm 0.21$ & $13.26 \pm 3.81$ \\
3 & $0.34 \pm 0.03$ & $1.66 \pm 0.08$ & $4.35 \pm 1.71$ & $26.97 \pm 5.70$ \\
\hline
\end{tabular}

Values are means \pm SEN.

${ }^{\circ}$ Growth, plateau and regression phases of the first dominant ovarian follicle, respectively.

beriods $I$ and 2 significantly different $(P<0.05)$.

'Periods 2 and 3 significantly different $(P<0.05)$.

Table 2. Pulse amplitude of hormones in five heifers during three sampling periods defined with reference to the growth of the first dominant follicle

\begin{tabular}{lcrr}
\hline & \multicolumn{3}{c}{ Hormone } \\
\cline { 2 - 4 } Period $^{\mathrm{a}}$ & $\begin{array}{c}\mathrm{LH} \\
\left.(\mathrm{ng} \mathrm{ml})^{-1}\right)\end{array}$ & $\begin{array}{c}\text { Oestradiol } \\
\left.(\mathrm{pg} \mathrm{m})^{-1}\right)^{\mathrm{b}}\end{array}$ & $\begin{array}{c}\text { Progesterone } \\
\left.(\mathrm{ng} \mathrm{m})^{-1}\right)\end{array}$ \\
\hline 1 & $0.29 \pm 0.02$ & $11.97 \pm 2.44$ & $7.26 \pm 3.14$ \\
2 & $0.38 \pm 0.03$ & $3.41 \pm 0.78$ & $11.73 \pm 2.18$ \\
3 & $0.48 \pm 0.12$ & $6.14 \pm 2.77$ & $34.25 \pm 11.43$ \\
\hline
\end{tabular}

Values are means \pm seM.

"Growth, plateau and regression phases of the first dominant ovarian follicle, respectively.

"Periods 1 and 2 significantly different $(P<0,05)$.

\section{Results and Discussion}

The three sampling periods were (mean \pm SEM) $2.5 \pm 0.2$ days, $5.6 \pm 0.3$ days and $8.2 \pm 0.4$ days after ovulation, for the growth, plateau and regression phases, respectively. Diameter of the first dominant ovarian follicle increased from $6.8 \pm 0.5 \mathrm{~mm}$ to $9.8 \pm 0.2 \mathrm{~mm}(P=0,006)$ between the first and second sampling periods, but did not change between the second and third periods $(P=0.26)$. Mean concentration and amplitude of pulses of oestradiol were greater $(P<0.05)$ during the growth compared with the plateau phase (Tables $I$ and 2), suggesting that aromatase activity in the dominant follicle is not maximal when maximum follicle diameter is attained. Similarly, Guilbault et al, (1993) reported peak plasma concentrations of oestradiol occurring about four days before cessation of growth of the first dominant follicle. Frequency of pulses of LH, oestradiol and progesterone tended to change in a coordinated fashion (Fig. I), being greatest during the growth phase of the dominant follicle, when circulating concentrations of progesterone were $<1,0 \mathrm{ng} \mathrm{ml}^{-1}$. There was little indication of pulsatile secretion of FSH. However, mean concentrations were high during the plateau phase (Table 1), approximately two days before the day of emergence of the second dominant follicle. This finding is in agreement with previous reports of increased concentrations of FSH preceding the emergence of a new wave of ovarian follicular growth (Adams et al., 1992). 


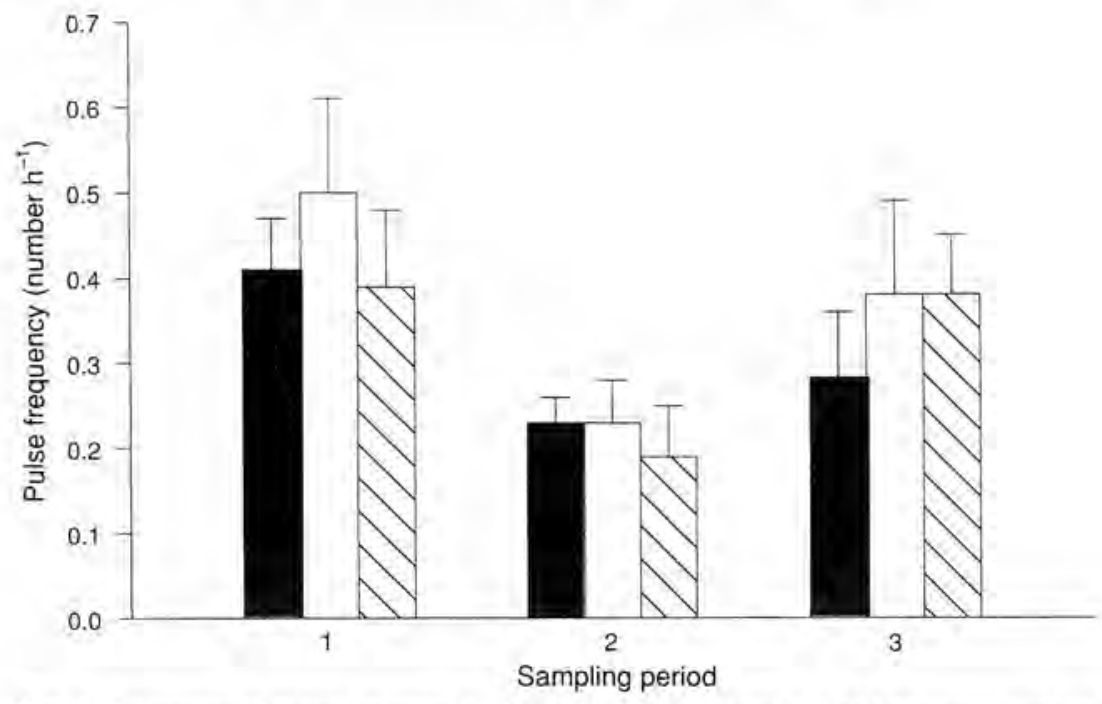

Fig. 1. Frequency of pulses (number $\mathrm{h}^{-1}$ ) of $\mathrm{LH}(\mathbf{⿴ 囗 十 )})$, oestradiol $(\square)$ and progesterone (国) in five heifers (mean \pm SEM) during the three sampling periods (growth, plateau and regression phases of the first dominant ovarian follicle, respectively).

\section{Conclusion}

Ovarian venous concentrations of oestradiol were greatest during the growth phase of the dominant follicle and were significantly reduced when the dominant follicle attained maximum diameter. Frequency of pulses of $\mathrm{LH}$, oestradiol and progesterone tended to change in a coordinated fashion and were greatest during the growth phase. Mean concentrations of FSH were greater during the plateau phase, approximately 2 days before emergence of the second dominant follicle, compared with the regression phase. This increase in FSH, in conjunction with the decrease in oestradiol, may be an indication of loss of functional dominance by the first dominant follicle of the oestrous cycle.

This study was partially funded by the Australian Meat Research Corporation. Assay reagents were kindly provided by D. Bolt. USDA Animal Hormone Program and the NIDDK (LH assay), J. Dias (FSH assay) and N. Mason (17 $\beta$-oestradiol assay). The authors thank G. De'ath for statistical advice, S. Stobart, C. Coleman and J. Cave for assistance in animal handling and collection of blood samples and D. Clopton for assistance with hormone assays.

\section{References}

Adams GP, Matteri RL, Kastelic JP, Ko JCH and Ginther OJ (1992) Association between surges of follicle-stimulating hormone and the emergence of follicular waves in heifers Journal of Reproduction and Fertility 94 177-188

Benoit AM and Dailey RA (1991) Catheterization of the caudal vena cava via the lateral saphenous vein in the ewe. cow, and gilt: an alternative to utero-ovarian and medial coccygeal vein catheters loumal of Animal Science 69 2971-2979

Guilbault LA, Bolamba D, Desaulniers DM and Lussier JG (1993) Follicular and hormonal events associated with the transient increase in estradiol concentrations during the first wave of follicular development in cattle Theriogenology 39 228. (Abstract)

Jolly PD (1992) Physiolegical and Nutritional Aspects of Posipartum Acyclicity in Bos indicus Cotos, PhD thesis, James Cook University of North Queensland
Kojima N, Stumpf TT, Cupp AS, Werth LA, Roberson MS, Wolfe MW, Kittok RJ and Kinder JE (1992) Exogenous progesterone and progestins as used in estrous synchrony regimens do not mimic the corpus luteum in regulation of luteinizing hormone and 173 -estradiol in circulation of cows Biology of Reproduction 47 1009-1017

Merriam GR and Wachter KW (1982) Algorithms for the study of episodic hormone secretion American Joumal of Physiology $243 \quad 310-318$

Norman ST and Fields MJ (1993) Ultrasound guided cannulation of the caudal vena cava in the bovine for selective sampling of ovarian effluent Theriogenology $39691-701$

Rahe $\mathrm{CH}$, Owens RE, Fleeger JL, Newton $\mathrm{HI}$ and Harms PG (1980) Pattern of plasma luteinizing hormone in the cyclic cow: dependence upon the period of the cycle Endocrinalogy $107 \quad 49 g-503$ 
Savio JD, Keenan L, Boland MP and Roche JF (1988) Pattern of growth of dominant follicles during the oestrous cycles of heifers Journal of Reproduction and Fertility $\mathbf{8 3}$ 663-071

Walters DL, Schams D and Schallenberger E (1984) Pulsatile secretion of gonadotrophins, ovarian steroids and ovarian oxytocin during the luteal phase of the oestrous cycle in the cow Journal of Reproduction and Feriility $\mathbf{7 1}$ 479-491

Wolfe MW, Stumpf TT, Roberson MS, Wolfe PL, Kittok RJ and Kinder JE (1989) Estradiol influences on pattern of gonadotropin secretion in bovine males during the period of changed responses to estradiol feedback in age-matched females Biology of Reproduction 41 626-634 